\title{
Isolation, Serotyping, and Antibiogram of Salmonella Isolates from Raw Milk Sold at Retail Vending in Erbil City, Iraq
}

\author{
Dhary Alewy ALMASHHADANY* and Ardalan Abdulhamed OSMAN \\ Knowledge University Research Center, Erbil, Kurdistan Region, Iraq \\ "corresponding author: dhary.hammed@Knowledge.edu.krd
}

Bulletin UASVM Animal Science and Biotechnologies 76(2)/ 2019

Print ISSN 1843-5262; Electronic ISSN 1843-536X

DOI:10.15835/buasvmcn-asb: 0020.19

\begin{abstract}
Pathogenic strains of Salmonella cause gastroenteritis in humans globally.This study aimed to determine the prevalence and antibiotic susceptibility pattern of Salmonellain raw milk sold in Erbil city, Kurdistanregion, Iraq. A total of 470 samples were collected from retail vendors between January and June 2019. Samples were cultured on selective media followed by serotyping and antibiotic sensitivity testing by disk diffusion assay.The results revealed that the overall prevalence of Salmonella was 7.9\%. The isolates belonged to nine (9) different serotypes: S.Typhimurium 18.9\%, S.Anatum 10.8\%, S.Muenchen 13.6\%, S.Enteritidis 10.8\%, S.Senftenberg 8.1\%, S. Newport $10.8 \%, S$. Arizona 10.8\%, S. Montevideo 8.1\%, and S.Dublin 8.1\%. The antibiotic resistance profile revealed that $67.6 \%, 62.2 \%, 56.8 \%$, and $56.8 \%$ of isolates were resistant to levofloxacin, streptomycin, imipenem, and tetracycline respectively. This resistance among Salmonella maypose a public health threat that needs activesafety measures and response.
\end{abstract}

Keywords:Salmonella, Serotyping, Raw milk,Antibiogram, Erbil, Kurdistan region, Iraq.

\section{Introduction}

Salmonella is one of the most frequently isolated foodborne pathogens globally. The pathogenic potential of Salmonella was documented in 1885 in pigs by two American pioneer scientists; Daniel E. Salmon and Theobald Smith (Octavia and Lan, 2014; Al-Gamal et al., 2019). Salmonella is found in the intestinal tract of animals, birds, and wide range of mammalian hosts including humans.As a result, it is widely distributed in nature and capable of surviving for a number of weeks in dry environmentsandvarious months in water. To date, more than 2,600 serotypes of Salmonella exist. In humans, the pathogenic strains have the potential to cause lifethreatening infections, most of which are foodborne diseases (Maserati et al., 2017; Ammar et al.,
2019).Salmonella strains are generally classified into two categories; Typhoidalsalmonellae and Non-typhoidal salmonellae. The former group includes strains that may cause typhoid fever or paratyphoid fever such as Typhi, Paratyphi A, Paratyphi B, and Paratyphi C, which is carried only by humans. Non-typhoidal salmonellae group includes all other Salmonella strains carried by humans, different types of animals, poultry, wild birds, and flies. Non-typhoidal salmonellae are the most common strains implicated in food poisoning(Ferede, 2014; El-Prince et al., 2019).

According to WHO statistics, about 1.3 billion cases of non-typhoidal salmonellosis occur globally each year. Around 80.3 million cases (85.6\%) are food borne. The predominant serotypes, the foods associated with non-typhoidal salmonellosis, and 
the trends of non-typhoidal salmonellosis are different in different region of the world. The disease is most common in children andreaches its peak during summer and fall seasons. In the developing countries, salmonellosis contributes to diarrhea morbidity and mortality of childhood, assalmonellae are accountable for about $20 \%$ of childhood illness cases (Majowicz et al., 2010; Stephen and Barnett, 2016; Katiyo et al., 2019). Some Salmonella serotypes are host-specific, while otherserovars have a more generic host range. Serotypes that cause asymptomatic infection in animal can result in human infections and vice versa (USDA, 2013; Balasubramanian et al., 2019). High-risk individuals for salmonellosis are infants, elderly, immunocompromised individuals and those who have gastric hypoacidity (Acheson and Hohmann, 2001; Coburn et al., 2007; Gutema et al., 2019).

The major sources of Salmonellosis in humans are different types of food, particularly ready-toeat food and fast food including different types of meats and meat products. It is known that Salmonella remains viable for long periods of time in frozen foods. Milk-borne salmonellosis is often related to the consumption of raw or inadequately pasteurized milk. However, Salmonella serovars may also contaminate dairy products during and after the pasteurization process (Almashhadany, 2008; Shafini et al., 2017; El Bagoury et al., 2019).

In Kurdistan region (Iraq), raw milk and dairy products are common served, with ease access, in food outlets especially in restaurants,retail outlets, street vendors, hotel, school, canteen and even small outlets which involved different styles of preparations.Therefore, this work was conducted in order to determine the prevalence and antibiogram profile of Salmonella among milk sold at retail vending in Erbil city.

\section{Materials and Methods}

\section{Study design and sampling}

A total of 470 raw milksamples (125 cows, 110 buffaloes,115 sheep, and 120 goats) were collected under sterile and hygienic conditions during January to June 2019 in Erbil city according to previously published method (Al-Mashhadany, 2014).

\section{Isolation and Identification of Salmonella}

Isolation of Salmonella from raw milk was done according topreviously published protocol
(WHO, 2010).Gram stain was done for all suspected Salmonella colonies (Casey et al., 2004; Cheesbrough, 2006), followed by biochemical identification tests according to standardized procedures (Cheesbrough, 2006; WHO, 2010). The biochemical tests included TSI, Urease, Lysine decarboxylase, citrate utilization test, MR-VP, indole test, mannitol fermentation, and motility.

\section{Serotyping of isolates}

All Salmonella isolates that showed typical biochemical reactions were subjected toserotyping by slide agglutination using Remel $®$ kitaccording to manufacturer instructions (Remel Europe Ltd., UK).

\section{Antibiotics susceptibility testing}

Disk diffusion assay on Mueller-Hinton agar (Oxoid, UK) was employed to evaluate the susceptibility of Salmonella isolates to a panel of twelve commonly used antibiotics (HiMedia, India). The guidelines of CLSI were followed to perform the Modified Kirby-Bauer method and to interpret the inhibition zones diameters around antibiotic disks (CLSI, 2011). The tested antibiotics were; amikacin $\left(\mathrm{AK}_{10}\right)$, amoxicillin $\left(\mathrm{AMC}_{25}\right)$,cefadroxil $\left(\mathrm{CFR}_{30}\right)$, cefotaxime $\left(\mathrm{CTX}_{30}\right)$,ceftriaxone $\left(\mathrm{CRO}_{30}\right)$, gentamicin $\left(\mathrm{GM}_{15}\right)$, imipenem (IMP $\left.{ }_{10}\right)$, kanamycin $\left(\mathrm{KAN}_{30}\right)$, levofloxacin $\left(\mathrm{LEV}_{5}\right)$, streptomycin $\left(\mathrm{STR}_{10}\right)$, tetracycline $\left(\mathrm{TEC}_{30}\right)$, and tobramycin $\left(\mathrm{TM}_{10}\right)$.

\section{Statistical analysis}

All data was analyzed via version 21 of SPSS software package. Confidence intervals were calculated by normal approximation method. Chi square test was employed to test for difference between groups. Significance level was set to 0.05 .

\section{Results}

\section{Prevalence of Salmonella in milk}

Out of 470 raw milk samples, $7.9 \%$ (37) were positive for the presence of Salmonella. Of note, $10.4 \%(13 / 125)$ of samples from cow milkand $5.5 \%(6 / 110)$ of buffaloes milk harbored Salmonella (Table1). Based on statistical inference, it is estimated that $5.46 \%-10.34 \%$ (95\% confidence interval) of raw milk among Erbil retail vending is contaminated by Salmonella species (Table 1).There is no significant difference between types of milk in terms of Salmonella prevalence $\left(\chi^{2}=1.586, p=0.363\right)$.

\section{Detected serotypes of Salmonella}

Regarding serotyping of Salmonella isolated from different types of raw milk, nine (9) different 
Table 1.Prevalence of Salmonella among raw milk samples.

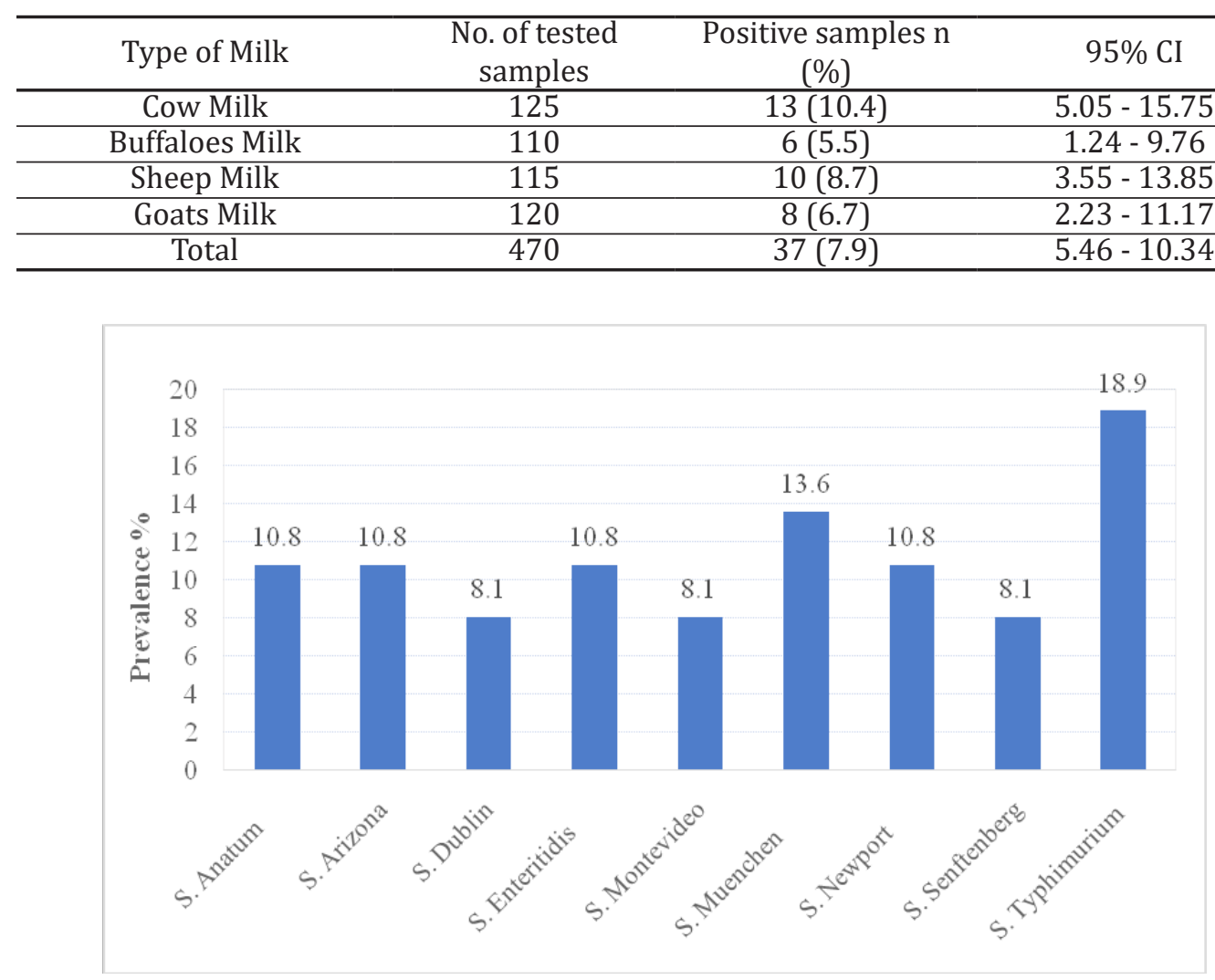

Figure 1.Salmonella serotypes isolated from raw milk

Table 2. Temporal distribution of Salmonella in raw milk samples

\begin{tabular}{ccccccc}
\hline \multirow{2}{*}{ Month } & \multicolumn{3}{c}{ No. of examined milk (No. of positive) } & \multicolumn{2}{c}{ Total } & No. of positive \\
& Cow & Buffalos & Sheep & Goats & examined & $(\%)$ \\
\hline January & $21(1)$ & $17(0)$ & $19(0)$ & $19(1)$ & 76 & $2(2.6)$ \\
\hline February & $20(0)$ & $19(0)$ & $20(1)$ & $21(0)$ & 80 & $1(1.3)$ \\
\hline March & $22(2)$ & $18(1)$ & $20(3)$ & $21(1)$ & 81 & $7(8.6)$ \\
\hline April & $21(2)$ & $20(2)$ & $19(1)$ & $19(1)$ & 79 & $6(7.6)$ \\
\hline May & $20(3)$ & $18(1)$ & $19(2)$ & $20(2)$ & 77 & $8(10.4)$ \\
\hline June & $21(5)$ & $18(2)$ & $18(3)$ & $20(3)$ & 77 & $13(16.9)$ \\
\hline Total & $125(13)$ & $110(6)$ & $115(10)$ & $120(8)$ & 470 & $37(7.9)$ \\
\hline
\end{tabular}

serotypes were detected. The most common serotypes detected were S.Typhimurium (18.9\%) and $S$.Muenchen (13.6\%), while S.Dublin, $S$. Montevideo, and S.Senftenberg were the least detected. Other serotypes and their percentages are depicted graphically in Figure 1.

\section{Temporal distribution of Salmonella}

A change in prevalence rate of Salmonella was observed through study period. The highest rates of prevalence were detected in June (16.9\%) and May $(10.4 \%)$, while the lowest rate was found in February (1.3\%). Table 3 summarizes the detection ratesin different milk samples in a temporal scale.Of note, spring season and early summer were associated with gradual increase in Salmonella prevalence $\left(r^{2}=0.854\right)$ (Figure 2).

\section{Antimicrobial susceptibility of detected Salmonella}

All Salmonella isolates $(\mathrm{n}=37)$ were tested against twelve commonly used antibiotics. Total sensitivity was found towards amoxicillin and cefadroxil, while high resistance phenotypes to levofloxacin $(67.6 \%)$ and streptomycin $(62.2 \%)$ were found. The detailed 


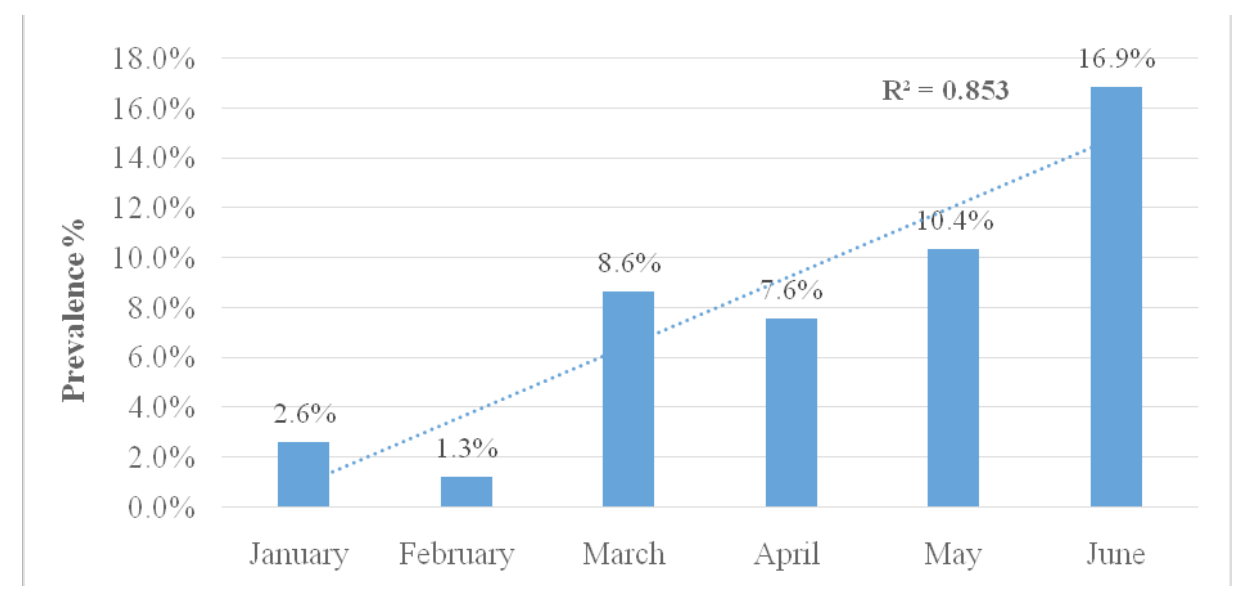

Figure 2. Association between months and prevalence of Salmonella

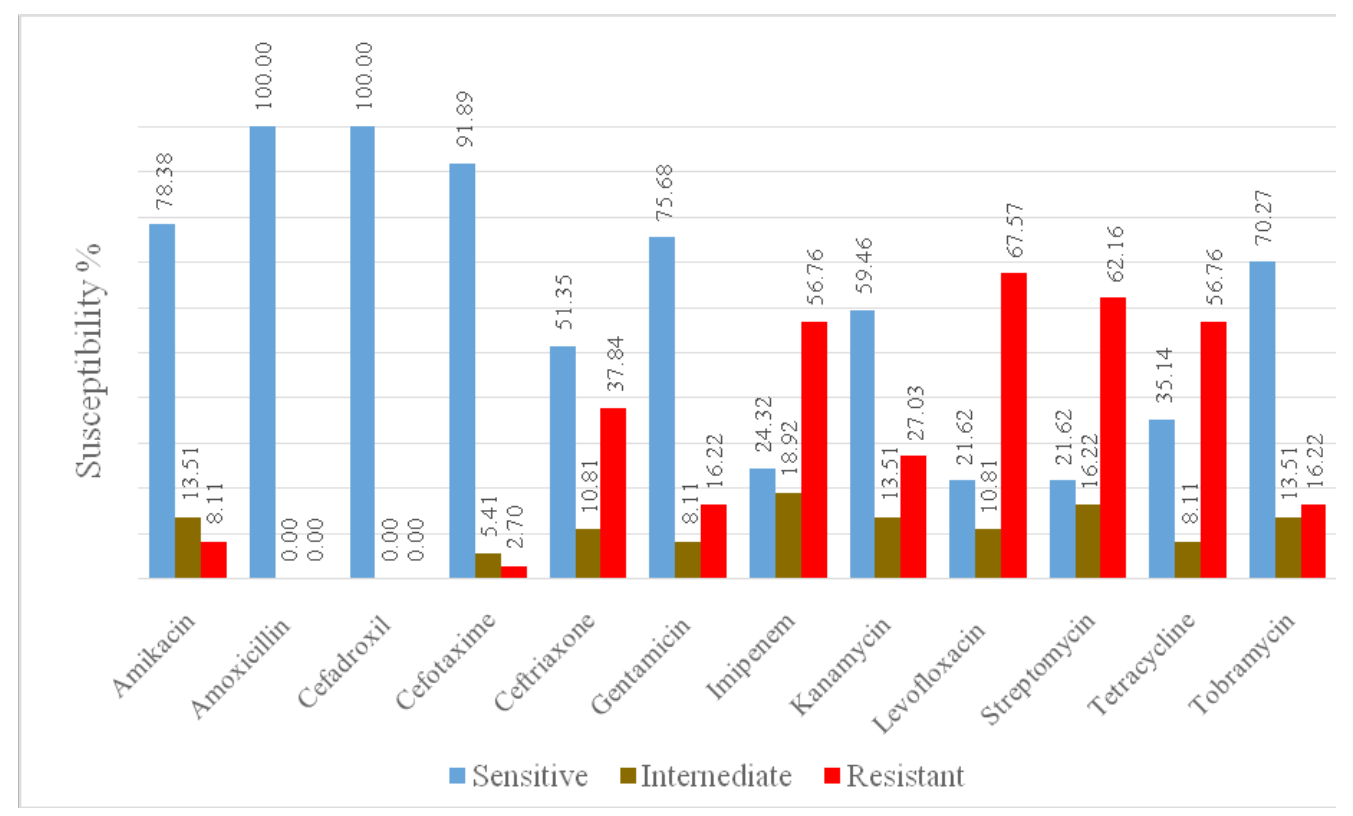

Figure 3. Antibiogram of Salmonella species to a panel of 12 antibiotics

antibiogram profile is summarized graphically in figure 3.

\section{Discussion}

Salmonellosis is a major cause of human bacterial gastroenteritis in both developed and developing countries. It has been reportedby theWorld Health Organization (WHO) and Food Agriculture Organization (FAO) as the most prevalent and considerable zoonosis since 1950. Several studies have revealed the importance of milk and dairy products in transmission of Salmonella and development of salmonellosis in humans (Tacket et al., 1985; Mazurek et al., 2004; Dominguez et al., 2009; van Duynhoven et al.,
2009; Giacometti et al., 2015; Putturu et al., 2015; Ung et al., 2019).

In the present study, the prevalence of Salmonella among raw milk samples from different animals was $7.9 \%$ (Table 1). Our results were consistent with Rastegarand associates in Iran, who found the total isolation rate of Salmonella among milk samples to be $11 \%$ by culture-dependent approach, while higher rate $(17 \%)$ was found by PCR method (Rastegar et al., 2013). Moreover, the overall prevalence is also in good agreementwith the study conducted by Almashhadany in Yemen (Al-Mashhadany, 2014), who found the total prevalence in different milk samples was $7.3 \%$. On the contrary, our results are in constant with 
studies from Egypt (15\%), Bangladesh (25.7\%), and Iraq (36\%) (Yasmin et al., 2015; El-Baz et al., 2017; Hasan, 2017).These variations are well-known globally andare influenced by many factors including: geographic, temporal, food type contaminated with salmonellae, and detection method (Besser, 2018).

Regarding Salmonella serovars isolated in this study (Figure 1), $S$. Typhimuriumwas the most prevalent (18.9\%), which isconsistentwith earlier reports from Yemen (Al-Mashhadany, 2014), Egypt (El-Baz et al., 2017), and a recent study isolated Salmonella from grilled chicken meat in Erbil (Almashhadany, 2019). It is well-known that environmental spreading of Salmonellaserotypes is influenced by several ecological factors (Andino and Hanning, 2015).In terms of time-based occurrence of Salmonella, the highest prevalence was in June (16.9\%) and May (10.4\%) (Figure 2). Several studies had connected warm period to high occurrence of Salmonella. In USA, the overall case counts of salmonellosis reported to peak in summer $(38.6 \%)$ and were lowest in winter $(14.5 \%)$. They also found that Salmonella serotypes may vary in their normal reservoirs, environmental, seasonal spreading, and their ability to cause human infections (Judd et al., 2019).

Antibiotics resistance in Salmonella increases continually. Indeed, monitoring reports showed a two-fold increase in Salmonella resistant phenotypes (from 20\%-30\% to more than 70\%) from early 1990s to 2000s (Su et al., 2004). In this study, the sensitivity testing showed that $67.6 \%, 62.2 \%$, and $56.8 \%$ resistance to levofloxacin, streptomycin, imipenem, and tetracycline respectively (Figure 3). The usage of antimicrobials in food producing animals, such as cattle, buffaloes, ewes, and goats, could result in antibiotic resistant strains including Salmonella species. The antibiotic resistance of Salmonella Typhimurium isolates recovered from the food chain was studied recently (Wang et al., 2019). The most frequently observed antibiotic resistance patterns found in S.Typhimurium were tetra-resistant pattern ASSuT (ampicillin, streptomycin, sulfonamides, and tetracycline), and the penta-resistant pattern ACSSuT (ampicillin, chloramphenicol, streptomycin, sulfonamides, and tetracycline). However, a total sensitivity to levofloxacin, ceftriaxone, gentamicin was reported in Salmonella recovered from milk and dairy products in Slovakia (Hleba et al., 2011). The emergence of multidrug resistant Salmonella is known to complicate the control of food safety and clinical treatment of infections (Eng et al., 2015).

\section{Conclusion}

Salmonellosis is a significant foodborne disease that worth an additional research in Erbil city. The prevalence of Salmonella in raw milk samples is alarming. Moreover, detected serovars showed different degrees of resistance to important antibiotics used in food industry and clinical medicine. Molecular and epidemiological studies should follow this study to evaluate the hazard for consumers and inspection of antibiotic resistance determinants dissemination. A fourseason study is recommended to determine the changing epidemiology of Salmonella in milk.

\section{References}

1. Acheson D, Hohmann EL (2001). Nontyphoidal Salmonellosis. ClinInfect Dis. 32, 263-269.https://doi. org/10.1086/318457

2. Al-Gamal MS, Ibrahim GA, Sharaf OM, Radwan AA, Dabiza NM, Youssef AM, El-ssayad MF (2019). The protective potential of selected lactic acid bacteria against the most common contaminants in various types of cheese in Egypt.Heliyon 5, e01362.https://doi.org/10.1016/j. heliyon.2019.e01362

3. Al-Mashhadany D (2014). Prevalence of Salmonella spp. in Raw milk in Thamar Province, Yemen. Journal of King Saud University, 26, 33-39.

4. Almashhadany D (2008). Hygienic Significance of Salmonella among Red Meat in Thamar City. Thamar University Journal, 9, 73-84.

5. Almashhadany D (2019). Occurrence and antimicrobial susceptibility of Salmonella isolates from grilled chicken meat sold at retail outlets in Erbil City, Kurdistan region, Iraq. Ital J Food Saf. 8.https://doi.org/10.4081/ ijfs. 2019.8233

6. Ammar AM, Abdeen EE, Abo-Shama UH, Fekry E, KotbElmahallawy E (2019). Molecular characterization of virulence and antibiotic resistance genes among Salmonellaserovars isolated from broilers in Egypt. LettApplMicrobiol. 68, 188-195.https://doi. org/10.1111/lam.13106

7. Andino A, Hanning I (2015).Salmonella enterica: Survival, Colonization, and Virulence Differences among Serovars. Sci World J. 2015, 1-16.http://dx.doi. org/10.1155/2015/520179

8. Balasubramanian R, Im J, Lee JS, Jeon HJ, Mogeni OD, Kim JH, Rakotozandrindrainy R, Baker S, Marks F (2019). The global burden and epidemiology of invasive nontyphoidalSalmonella infections. Hum VaccinImmunother. 
15, 1421-1426.https://doi.org/10.1080/21645515.201 8.1504717

9. Besser JM (2018). Salmonella epidemiology: A whirlwind of change. Food Microbiol. 71, 55-59.https://doi. org/10.1016/j.fm.2017.08.018

10. Casey PG, Casey GD, Gardiner GE, Tangney M, Stanton C, Ross RP, Hill C, Fitzgerald GF (2004). Isolation and characterization of anti-Salmonella lactic acid bacteria from the porcine gastrointestinal tract.LettApplMicrobiol. 39, 431-438.https://doi.org/10.1111/j.1472765X.2004.01603.X

11. Cheesbrough M (2006). District Laboratory Practice in Tropical Countries, Part 2, (2nd ed.). Cambridge, Cambridge University Press.

12. CLSI (2011). Performance Standards for Antimicrobial Susceptibility Testing.M100-S21, 31; (1), Wayne.

13. Coburn B, Grassl GA, Finlay BB (2007). Salmonella, the host and disease: a brief review. Immunol Cell Biol. 85, 112-118.https://doi.org/10.1038/sj.icb.7100007

14. Dominguez M, Jourdan-Da Silva N, Vaillant V, Pihier N, Kermin C, Weill FX, Delmas G, Kerouanton A, Brisabois A, de Valk H (2009). Outbreak of Salmonella enterica Serotype Montevideo Infections in France Linked to Consumption of Cheese Made from Raw Milk. Foodborne Pathog. Dis. 6, 121-128.https://doi.org/10.1089/fpd.2008.0086

15. El-Baz A, El-Sherbini M, Abdelkhalek A, Al-Ashmawy M (2017).Prevalence and molecular characterization of Salmonellaserovars in milk and cheese in Mansoura city, Egypt.Journal of Advanced Veterinary and Animal Research, 4, 45-51.

16. El-Prince E, Hussein MF, El-Rahman AMA (2019). Incidence of Salmonella species in Table Eggs and some Egg-based Products.Journal of Advanced Veterinary Research, 9, 1-7.

17. El Bagoury A, Shelaby H, Saied H (2019). Incidence of Escherichia coli and Salmonella Species with Special Reference to Antibiotic Resistant Pathogenic E.coli Isolated From Locally Produced Cheeses in Egypt. Alexandria J Vet Sci. 60, 93-101.http://dx.doi.org/10.5455/ajvs.21944

18. Eng SK, Pusparajah P, AbMutalib NS, Ser HL, Chan KG, Lee LH (2015). Salmonella: A review on pathogenesis, epidemiology and antibiotic resistance. Front Life Sci. 8, 284-293.https://doi.org/10.1080/21553769.2015.1051 243

19. Ferede B (2014). Isolation, identification, antimicrobial susceptibility test and public awareness of Salmonella on raw goat meat at Dire Dawa Municipal Abattoir, eastern Ethiopia.MSc thesis, Addis Ababa University.https://hdl. handle.net/10568/43761

20. Giacometti F, Bonilauri P, Albonetti S, Amatiste S, Arrigoni N, Bianchi M, Bertasi B, Bilei S, Bolzoni G, Cascone G, Comin D, Daminelli P, Decastelli L, Merialdi G, Mioni R., Peli A, Petruzzelli A, Tonucci F, Bonerba E, Serraino A (2015). Quantitative Risk Assessment of Human Salmonellosis and Listeriosis Related to the Consumption of Raw Milk in Italy. J Food Prot. 78, 13-21.https://doi. org/10.4315/0362-028X.JFP-14-171

21. Gutema FD, Agga GE, Abdi RD, De Zutter L, Duchateau L, Gabriël S (2019). Prevalence and Serotype Diversity of Salmonella in Apparently Healthy Cattle: Systematic Review and Meta-Analysis of Published Studies, 20002017. Front Vet Sci. 6, 102.https://doi.org/10.3389/ fvets.2019.00102

22. Hasan AS (2017). Detection of Salmonella Spp. in milk samples of selected regions of Diyala city.Kufa Journal for Veterinary Medical Sciences, 8, 193-198.

23. Hleba L, Kačániová M, Pochop J, Lejková J, Čuboň J, Kunová S (2011). Antibiotic Resistance of Enterobacteriaceae Genera and Salmonella spp., Salmonella entericaSer. Typhimurium and Enteritidis Isolated from Milk, Cheese and Other Dairy Products from Conventional Farm in Slovakia. Journal of Microbiology, Biotechnology and Food Sciences, 1, 1-20.

24. Judd MC, Hoekstra RM, Mahon BE, Fields PI, Wong KK (2019). Epidemiologic patterns of human Salmonella serotype diversity in the USA, 1996-2016. Epidemiol Infect. 147, e187.https://doi.org/10.1017/ S0950268819000724

25. Katiyo S, Muller-Pebody B, Minaji M, Powell D, Johnson AP, DePinnaE,Day M,Harris R, GodboleG(2019).Epidemiology and Outcomes of NontyphoidalSalmonellaBacteremias from England, 2004 to 2015. J ClinMicrobiol.57, e0118918.https://doi.org/10.1128/JCM.01189-18

26. Majowicz SE, Musto J, Scallan E, Angulo FJ, Kirk M, O’Brien SJ, Jones TF, Fazil A, Hoekstra RM (2010).The Global Burden of NontyphoidalSalmonella Gastroenteritis.Clin Infect Dis. 50, 882-889.https://doi.org/10.1086/650733

27. Maserati A, Fink RC, Lourenco A, Julius ML, DiezGonzalez F (2017). General response of Salmonella entericaserovarTyphimurium to desiccation: A new role for the virulence factors sopD and sseD in survival. PLoS One 12, e0187692.https://doi.org/10.1371/journal. pone.0187692

28. Mazurek J, Salehi E, Propes D, Holt J, Bannerman T, Nicholson LM, Bundesen M, Duffy R, Moolenaar RL (2004).A Multistate Outbreak of Salmonella enterica Serotype Typhimurium Infection Linked to Raw Milk Consumption-Ohio, 2003.J Food Prot. 67, 2165-2170. https://doi.org/10.4315/0362-028X-67.10.2165

29. Octavia S, Lan R (2014). The Family Enterobacteriaceae. In: E. Rosenberg, E. F. DeLong, S. Lory, E. Stackebrandt, F. Thompson (Eds.), The Prokaryotes. (pp. 225-286).Berlin Heidelberg,Springer, https://doi.org/10.1007/978-3642-38922-1_167

30. Putturu R, Eevuri T, Ch B, Nelapati K (2015).Salmonella Enteritidis - Food Borne Pathogen - A review. International Journal of Pharmacy and Biological Sciences, 5, 86-95.

31. Rastegar H, Ashtiani HA, Andalibi M, Nehshabouri SH, Akbari M, Rassam H, Parvizi S, Anjarani S (2013). Detection, isolation and assessment of Salmonella Entiritidisin milk by conventional culture methods and real-time PCR in Iran.American Journal of Research Communication, 1, 81-97.

32. Shafini AB, Son R, Mahyudin NA, Rukayadi Y, Zainazor $\mathrm{T}$ (2017). Prevalence of Salmonella spp. in chicken and beef from retail outlets in Malaysia, International Food Research Journal, 24, 437-449 
33. Stephen DM, Barnett AG (2016). Effect of temperature and precipitation on salmonellosis cases in SouthEast Queensland, Australia: an observational study. BMJ Open 6, e010204.http://dx.doi.org/10.1136/ bmjopen-2015-010204

34. 34. Su LH, Chiu CH, Chu C, Ou JT (2004). Antimicrobial Resistance in NontyphoidSalmonella Serotypes: A Global Challenge. Clin Infect Dis. 39, 546-551.https://doi org/10.1086/422726

35. Tacket CO, Dominguez LB, Fisher HJ, Cohen ML (1985). An Outbreak of Multiple-Drug-Resistant Salmonella Enteritis from Raw Milk. J Am Med Assoc. 253, 2058.http://dx.doi. org/10.1001/jama.1985.03350380074024

36. Ung A, Baidjoe AY, Van Cauteren D, Fawal N, Fabre L, Guerrisi C, Danis K, Morand A, Donguy MP, Lucas E, Rossignol L, Lefèvre S, Vignaud ML, Cadel-Six S, Lailler R, JourdanDa Silva N, Le Hello S (2019). Disentangling a complex nationwide Salmonella Dublin outbreak associated with raw-milk cheese consumption, France, 2015 to 2016.Euro Surveill. 24.https://dx.doi.org/10.2807\%2F1560-7917. ES.2019.24.3.1700703

37. USDA (United States Department of Agriculture). Salmonella Questions \& Answers (2013).https://www. fsis.usda.gov/shared/PDF/Salmonella_Questions_and_ Answers.pdf?redirecthttp=trueAccessed 26.09.19.
38. VanDuynhoven YTHP, Isken LD, Borgen K, Besselse $\mathrm{M}$, Soethoudt K, Haitsma O, Mulder B, Notermans DW, De Jonge R, Kock P, Van Pelt W, Stenvers O, Van Steenbergen J (2009). A prolonged outbreak of SalmonellaTyphimurium infection related to an uncommon vehicle: hard cheese made from raw milk. Epidemiol Infect. 137, 1548-1557. https://doi.org/10.1017/S0950268809002337

39. Wang X, Biswas S, Paudyal N, Pan H, Li X, Fang W, Yue M (2019). Antibiotic Resistance in SalmonellaTyphimurium Isolates Recovered from the Food Chain Through National Antimicrobial Resistance Monitoring System Between 1996 and 2016. FrontMicrobiol. 10, 985.https://doi. org/10.3389/fmicb.2019.00985

40. WHO Global Foodborne Infections Network (2010). Laboratory Protocol 'Isolation of Salmonella spp. From Food and Animal Faeces. Available from: http:// antimicrobialresistance.dk/CustomerData/Files/ Folders/6-pdf-protocols/63_18-05-isolation-ofsalm-220610.pdf

41. Yasmin S, Parveen S, Munna S, Noor R (2015). Detection of Salmonella spp. and Microbiological Analysis of Milk and Milk Based Products Available within Dhaka Metropolis, Bangladesh. British Microbiology Research Journal, 5, 474-480. 